\title{
Effect of grain refinements on the microstructure and thermal behaviour of $\mathrm{Mg}-\mathrm{Li}-\mathrm{Al}$ alloy
}

\author{
Mariusz Król ${ }^{1}$ (D)
}

Received: 24 July 2017 / Accepted: 22 March 2018/Published online: 4 April 2018

(C) The Author(s) 2018

\begin{abstract}
The light as-cast $\mathrm{Mg}-9 \mathrm{Li}-1.5 \mathrm{Al}$ alloys were manufactured and modified by 0.2 mass\% $\mathrm{Zr}$, commercial 0.2 mass $\%$ TiBor and 0.2 mass \% AlSr master alloys. The thermal derivative analysis using UMSA platform was utilised to characterise a crystallisation process. Samples were heated up to $700{ }^{\circ} \mathrm{C}$ and then freely cooled down $\left(\sim 0.6^{\circ} \mathrm{C} \mathrm{s}{ }^{-1}\right)$ to ambient temperature in order to simulate the natural cooling of casts. Dilatometry study was used to identify changes in solid state. The relative elongation of unmodified and modified alloys was measured in the temperature range from 20 to $400{ }^{\circ} \mathrm{C}$, with a heating rate $1.0^{\circ} \mathrm{C} \mathrm{s}^{-1}$. The effects of $\mathrm{Zr}$, TiBor and AlSr content on the microstructure of analysed magnesium alloys were investigated. Evaluation of microstructure was identified by light microscope, scanning electron microscopy, X-ray diffraction and energy-dispersive X-ray spectroscopy. The results showed that the addition of TiBor reduced the grain size of $\mathrm{Mg}-9 \mathrm{Li}-1.5 \mathrm{Al}$ cast alloy from 930 to $530 \mu \mathrm{m}$, while the addition of AlSr master alloy reduced the grain size to $480 \mu \mathrm{m}$. Moreover, an addition of TiBor and AlSr simultaneously reduced the grain size to $430 \mu \mathrm{m}$. The addition of $\mathrm{Zr}$ causes a reduction in grain size to $630 \mu \mathrm{m}$. The addition of grain refinement causes changes in crystallisation process and variations in the coefficient of linear thermal expansion (CTE).
\end{abstract}

Keywords Magnesium-lithium alloys - Thermal expansion - Thermal derivative analysis · Grain refinement

\section{Introduction}

Following the World War II, Mg-Li-based alloys, as an emerging light structural metallic material, have been presumed to be extensively used in aerospace and civilian areas, such as transport, electronics packaging and sports manufacturing for their high specific strength and specific stiffness, excellent damping and electromagnetic shielding properties $[1,2]$.

In the beginning, the analysis of Mg-Li-based alloys and composites including applications, microstructures, mechanical properties and processing technologies was regularly presented. Furthermore, the development in the research of intermetallic particles reinforced $\mathrm{Mg}-\mathrm{Li}$ matrix composites was studied [3, 4].

Mariusz Król

mariusz.krol@polsl.pl

1 Institute of Engineering Materials and Biomaterials, Faculty of Mechanical Engineering, Silesian University of Technology, Konarskiego 18a St., 44-100 Gliwice, Poland
Mg-Li-based alloys are the lightest among the magnesium alloys and serve as the important structural materials for aerospace industry. They maintain high cold formability, and the problems of magnesium-lithium binary alloys, such as poor resistance to corrosion and low strength, limit their utilisation [5].

There are few standard ways to enhance the strength of metallic materials through decreases in grain size and can be divided into two groups like thermal and chemical methods. The thermal method of grain refinement is superheating, and chemicals are zirconium, carbon, silicon carbide, manganese, titanium, calcium, strontium, antimony, cerium additions and Elfinal process [6, 7].

The additional methods capable of raising the strength are an addition of alloying elements. The increase in a third element-for example aluminium - to Mg-Li-based alloys serves to change the strength relating to intermetallic particle formation [1, 3].

The mechanical properties of $\mathrm{Mg}-\mathrm{Li}$ alloys increase apparently with the addition of $\mathrm{Al}$ content, during the elongation of alloys reduces dangerously when the $\mathrm{Al}$ 
content is higher than 6 mass $\%$. Titanium, strontium and zirconium are also a useful alloying element to improve $\mathrm{Mg}-\mathrm{Li}$ properties [2, 6].

According to the $\mathrm{Mg}-\mathrm{Li}$ binary phase diagram, if the $\mathrm{Li}$ content is less than around 5.5 mass $\%$, the metal is formed of a single $\alpha(\mathrm{Mg})$ phase with hcp structure. When the $\mathrm{Li}$ content is within 5.5 and 11 mass \%, the hcp $\alpha(\mathrm{Mg})$ phase coexists with bcc-structured $\beta(\mathrm{Li})$ phase, while the structure has only a single bcc-structured $\beta(\mathrm{Li})$ phase when the Li content is higher than 11 mass\% $[8,9]$.

Nucleation of the primary phase is the initial step in the transition of molten alloys into the solid state. Nucleation control has been the subject of many studies $[10,11]$. In the case of $\mathrm{Mg}$ alloys, a finer grain size increases most mechanical properties, including yield strength due to the high Hall-Petch coefficient, corrosion resistance and creep resistance [12-15].

In this study, the ternary alloys $\mathrm{Mg}-9 \mathrm{Li}-1.5 \mathrm{Al}$ (mass\%) were manufactured and modified by processed by commercial $\mathrm{Zr}$, TiBor and AlSr master alloys. The microstructure evolution, thermal derivative analysis, dilatation, scanning electron microscopy, X-ray diffraction and energy-dispersive $\mathrm{X}$-ray spectroscopy techniques were used to examine the effect of grain refinements.

\section{Experimental}

Within the framework of the present work, alloys of magnesium with lithium and aluminium and with $\mathrm{Zr}$, TiBor and $\mathrm{AlSr}$ as grain refinement have been melted, casted and examined. The raw materials used in these experiments were magnesium with technical grade (min. $99.5 \% \mathrm{Mg}$ ), aluminium 3N8 $(99.98 \% \mathrm{Al})$, lithium $(99.9 \% \mathrm{Li})$, TiBor, $\mathrm{AlSr}$ and $\mathrm{Zr}$ as refinements were utilised. Melting and casting of alloys were carried out using laboratory vacuum induction furnace VSG 02 from the company Balzers. Melts held in a crucible of $\mathrm{Al}_{2} \mathrm{O}_{3}$ in shape of $\varnothing 60 \mathrm{~mm} \times$ $80 \mathrm{~mm}$, using the ceramic material sheath thermocouple for measuring the temperature of melting and casting alloys. Melting temperature was approx. $700 / 720{ }^{\circ} \mathrm{C}$ and the melting time approx. 5 min., which, taking into account the strong bath stirring electrodynamic eddy currents in enough for the complete homogenisation of the melt. Grain refinement was introduced at the end of the melting process from the vacuum containers. After placed of grain refinement in the alloy, melts kept in the liquid state for $2 \mathrm{~min}$, followed by the casting. The chemical composition of analysed $\mathrm{Mg}-\mathrm{Li}-\mathrm{Al}$ alloys and used grain refinements are given in Tables 1 and 2.

The linear thermal expansion coefficient of the investigated magnesium-lithium-aluminium alloys was measured in argon atmosphere using the Bahr 805A/D dilatometer
Table 1 Chemical compositions of analysed $\mathrm{Mg}-\mathrm{Li}-\mathrm{Al}$ alloys

\begin{tabular}{|c|c|c|c|c|c|}
\hline \multicolumn{6}{|c|}{ Elements/mass\% } \\
\hline $\mathrm{Li}$ & $\mathrm{Al}$ & $\mathrm{Zr}$ & TiBor & AlSr10 & $\mathrm{Mg}$ \\
\hline 9 & 1.5 & - & - & - & Balance \\
\hline 9 & 1.5 & 0.2 & - & - & Balance \\
\hline 9 & 1.5 & - & 0.2 & - & Balance \\
\hline 9 & 1.5 & - & - & 0.2 & Balance \\
\hline 9 & 1.5 & - & 0.2 & 0.2 & Balance \\
\hline
\end{tabular}

Table 2 Chemical composition of grain refinements

\begin{tabular}{lll}
\hline & Element & mass\% \\
\hline TiBor & $\mathrm{Ti}$ & 4.9 \\
& $\mathrm{~B}$ & 0.95 \\
& $\mathrm{Fe}$ & 0.17 \\
& $\mathrm{Si}$ & 0.06 \\
& $\mathrm{~V}$ & 0.09 \\
& $\mathrm{Al}$ & Balance \\
AlSr10 & $\mathrm{Sr}$ & 10.07 \\
& $\mathrm{Fe}$ & 0.13 \\
& $\mathrm{Si}$ & 0.08 \\
& $\mathrm{Ca}$ & $<0.10$ \\
& $\mathrm{Al}$ & Balance \\
\hline
\end{tabular}

over a temperature range from ambient temperature to $400{ }^{\circ} \mathrm{C}$ at heating and cooling rates of $1{ }^{\circ} \mathrm{C} \mathrm{s}^{-1}$. The thermocouple type $\mathrm{S}$ was utilised to measure changes in temperatures. Cylindrical samples in shape $10 \mathrm{~mm}$ in length and $4 \mathrm{~mm}$ in diameter were used in dilatometry test.

The thermal derivative analysis (TDA) was done on the prepared cylindrical samples in shape of $18 \mathrm{~mm}$ in diameter and $20 \mathrm{~mm}$ using UMSA device [10, 11, 14]. Samples were melted at $700{ }^{\circ} \mathrm{C}$ in an argon atmosphere. Following isothermal holding for $90 \mathrm{~s}$, all the melts were solidified and cooled to ambient temperature in the crucibles with argon protection in the furnace to minimise the oxidation.

The signal from the thermal derivative analysis was acquired using a high-speed National Instruments data acquisition system. The recorded data were analysed in Fityk software. The cooling curves and corresponding derivative curves were plotted to define thermal events, based on the first and second derivative of cooling curve. The test samples were solidified at an average cooling rate of approximately $0.6{ }^{\circ} \mathrm{C} \mathrm{s}^{-1}$ in the range of liquidus and solidus temperature. The cooling rate was determined using the following formula:

$\mathrm{CR}=\frac{T_{\mathrm{liq}}-T_{\mathrm{sol}}}{t_{\mathrm{sol}}-t_{\mathrm{liq}}}$ 
where $T_{\text {liq }}$ and $T_{\text {sol }}$ are the liquidus and solidus temperatures, respectively, and $t_{\text {liq }}$ and $t_{\text {sol }}$ the times from the cooling curve that correspond to liquidus and solidus temperatures, respectively.

The Newtonian method was applied in this research to determine the baseline. This means that the thermal gradient across the specimen is considered to be zero and that heat transfer between the casting and the mould occurs through convection. The Fourier method is another method used to calculate the baseline in which the positions of two thermocouples at the beginning and end of the solidification process are considered. However, it is much more complicated than the Newtonian method. Besides, a thermal contraction of the metal occurs during solidification, the exact positions of the two-thermocouple tips are difficult to estimate [16-18]. The base line has been predicted by the sixth polynomial fitting $(\mathrm{d} T / \mathrm{d} t)_{\mathrm{BL}}=a_{0}+a_{1} T+a_{2-}$ $t)_{\mathrm{BL}}=a_{0}+a_{1} T+a_{2} T^{2}+a_{3} T^{3}+a_{4} T^{4}+a_{5} T^{5}+a_{6} T^{6}$ between the beginning and the end of solidification in the first derivative curve. The sixth-order polynomial yields a correlation coefficient greater than 0.97 .

Metallographic specimens were horizontally sliced at the position that is $10 \mathrm{~mm}$ from the top. The as-cast grains of the etched samples were measured using polarised light in optical microscope Leica equipped Q-WinTM image analyser. The grain size was determined by the linear intercept method at the centre of transverse sections.

The X-ray qualitative and quantitative microanalysis and the analysis of a surface concentration of cast elements in the examined magnesium-lithium-aluminium unmodified and modified alloys have been made on the scanning electron microscope ZEISS SUPRA 35 with a system EDAX XM4 TRIDENT consisting of spectrometer EDS, WDS and EBSD $(20 \mathrm{kV}, 15 \mathrm{~mm}$ of work distance and $30 \mu \mathrm{m}$ of aperture).

Phase composition was determined by the X-ray diffraction technique utilising the $X^{\prime}$ 'Pert apparatus including a cobalt lamp with $40 \mathrm{kV}$ voltage. The calculation was done by angle range of $2 \Theta: 30^{\circ}-110^{\circ}$. The measurement step was $0.03^{\circ}$ in length while the pulse counting time was $30 \mathrm{~s}$.

Hardness tests were made using Zwick ZHR 4150 TK hardness tester in the HRF scale.

\section{Results and discussion}

The analysis of coefficient of linear thermal expansion of Mg-9Li-1.5Al (Table 3 and Fig. 1) has validated the fact that CTE depends on temperature. Untreated $\mathrm{Mg}-9 \mathrm{Li}-$ 1.5Al alloy has CTE about $29.4 \cdot 10^{-6} \mathrm{~K}^{-1}$, and with further increase in temperature to $250{ }^{\circ} \mathrm{C}$, CTE increases to $34.3 \cdot 10^{-6} \mathrm{~K}^{-1}$. Further increase in temperature to $400{ }^{\circ} \mathrm{C}$ caused a decrease in CTE to $31.9 \cdot 10^{-6} \mathrm{~K}^{-1}$. Analysis of the heating and cooling dilatometric curves of analysed materials modified by TiBor and AlSr is characterised by a linear decrease in linear expansion coefficient as a function of temperature. Moreover, based on changes in elongation during heating and cooling cycle, it was found that shape of

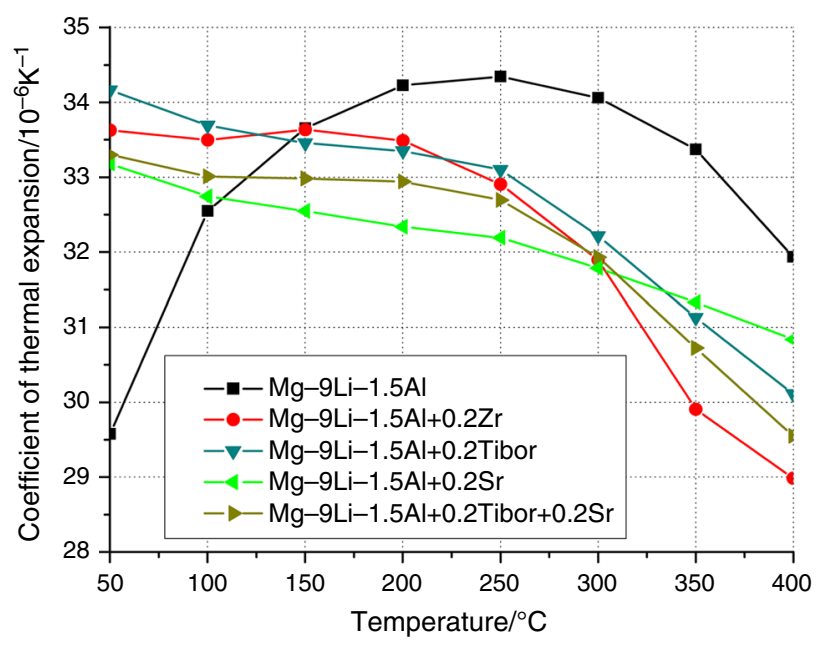

Fig. 1 Changes in coefficient of thermal expansion versus temperature of analysed $\mathrm{Mg}-\mathrm{Li}-\mathrm{Al}$ alloys

Table 3 Resume of thermophysical parameters of $\mathrm{Mg}-\mathrm{Li}-\mathrm{Al}$ alloys after dilatometry analysis

\begin{tabular}{llllllllll}
\hline Material & \multicolumn{3}{c}{ Linear coefficient of thermal expansion $\alpha / 10^{-6} \mathrm{~K}^{-1}$} & \multicolumn{3}{c}{ Max change in length/mm } \\
\cline { 2 - 10 } & 50 & 100 & 150 & 200 & 250 & 300 & 350 & 400 \\
\hline Mg-9Li-1.5Al & 29.5 & 32.5 & 33.6 & 34.2 & 34.3 & 34.0 & 33.3 & 31.9 & 1.205 \\
Mg-9Li-1.5Al+0.2Zr & 33.6 & 33.4 & 33.5 & 33.5 & 32.9 & 31.8 & 29.8 & 28.9 & 1.086 \\
Mg-9Li-1.5Al+0.2TiBor & 34.0 & 33.6 & 33.4 & 33.3 & 33.0 & 32.2 & 31.1 & 30.1 & 1.127 \\
Mg-9Li-1.5Al+0.2Sr & 33.2 & 32.5 & 32.4 & 32.3 & 32.1 & 31.7 & 31.3 & 30.8 & 1.156 \\
Mg-9Li-1.5Al+0.2TiBor+0.2Sr & 32.7 & 32.9 & 32.9 & 32.8 & 32.6 & 31.9 & 30.7 & 29.5 & 1.108 \\
\hline
\end{tabular}


graphs has a linear relationship that means no transitions in solid state occur.

The phase composition of the investigated alloys treated by grain refinements and untreated was examined by XRD technique. The XRD profile of unmodified alloy demonstrates that there are two phases- $\beta(\mathrm{Li})$ phase (matrix phase, a solid solution of magnesium in body-centred cubic (bcc) lithium lattice) and $\alpha(\mathrm{Mg})$ phase (solid solution of lithium in hexagonal close-packed (hcp) magnesium lattice), which is faithful with the observation using a light microscope. No peaks of $\mathrm{Al}$ including phase are noticed that suggests most of $\mathrm{Al}$ exists in a solid solution state. However, with the addition of $\mathrm{Zr}$, new peaks correspond to the $\mathrm{Zr}$ phases. Furthermore, with the addition of TiBor and $\mathrm{AlSr}$, no additional peaks were observed.
Optical micrographs of $\mathrm{Mg}-9 \mathrm{Li}-1.5 \mathrm{Al}$ cast alloy and after modification by $\mathrm{Zr}$, TiBor and $\mathrm{AlSr}$ are given in Fig. 2. It can be observed that the structure of the analysed alloys is fundamentally formed of light grey $\alpha(\mathrm{Mg})$ phase and dark grey $\beta$-Li phase, which is in consistent with the $\mathrm{Mg}-\mathrm{Li}$ binary system $[8,9]$. Most of the $\alpha(\mathrm{Mg})$ phase is elongated ribbon-like, where $\beta(\mathrm{Li})$ phase fills the area between $\alpha(\mathrm{Mg})$ phase grains, separated by boundaries between two phases. In the duplex phase matrix, the ratio of $\alpha$ and $\beta$ phases is $40 / 60$. There also exists some particlelike (Fig. 2e-marked in white circle) phase in the alloy. The granular-dispersive phase of the intermetallic compounds is randomly spread in the $\alpha$ and $\beta$ matrices. Darker particles have most probably resulted from the aluminium addition in the form of $\eta(\mathrm{LiAl})$ phase as suggested in
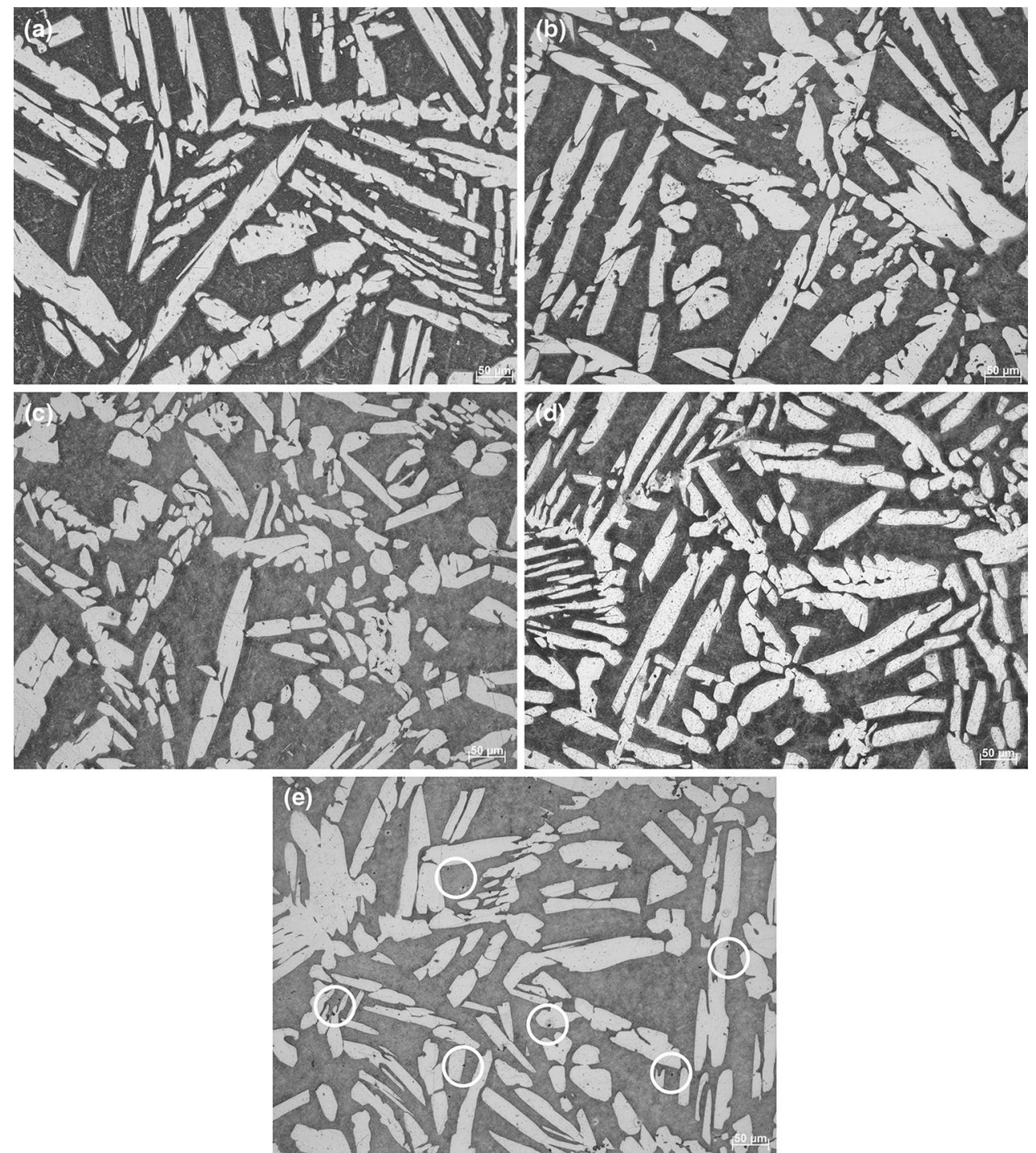

Fig. 2 Optical microstructure of as-cast and after modification of $\mathrm{Mg}-9 \mathrm{Li}-1.5 \mathrm{Al}$ alloy: a $\mathrm{Mg}-9 \mathrm{Li}-1.5 \mathrm{Al}, \mathbf{b} \mathrm{Mg}-9 \mathrm{Li}-1.5 \mathrm{Al}+0.2 \mathrm{Zr}$, c $\mathrm{Mg}-9 \mathrm{Li}-$ $1.5 \mathrm{Al}+0.2 \mathrm{TiB}$ or, $\mathbf{d ~ M g}-9 \mathrm{Li}-1.5 \mathrm{Al}+0.2 \mathrm{Sr}$, e Mg-9Li-1.5Al+0.2TiBor+0.2Sr 
$[8,9,19,20]$. SEM analysis of marked circles shows high concentration of $\mathrm{Al}$, indicating that it is $\eta(\mathrm{LiAl})$ phase. Moreover, the addition of grain refinements effects in the conversion of the elongated-striped $\alpha(\mathrm{Mg})$ phase with a blocky structure and rounded corners. Moreover, optical metallography indicated fully dense alloys.

Analysis of grain size of analysed alloys after thermal derivative analysis cooled at a rate of $0.6{ }^{\circ} \mathrm{C} \mathrm{s}^{-1}$ appointed by the method of linear interception length shows that the grain refining appearance is different for each alloy (Figs. 3 and 4). Once $\mathrm{Zr}$ is added, there is a significant reduction in grain size. The Mg-9Li-1.5Al alloy was refined from 930 to $640 \mu \mathrm{m}$ by 0.2 mass $\% \mathrm{Zr}$. The results showed that the addition of TiBor master alloy decreased the grain size of Mg-9Li-1.5Al cast alloy to $500 \mu \mathrm{m}$, while the addition of $\mathrm{AlSr}$ master alloy reduced the grain size to $480 \mu \mathrm{m}$.
Moreover, an addition of TiBor and AlSr simultaneously reduced the grain size to $430 \mu \mathrm{m}$. The relatively small grain size of $\mathrm{Mg}-9 \mathrm{Li}-1.5 \mathrm{Al}+0.2 \mathrm{TiBor}+0.2 \mathrm{Sr}$ is not obviously reflected in its hardness related to $\mathrm{Mg}-9 \mathrm{Li}-$ $1.5 \mathrm{Al}+0.2 \mathrm{TiBor}$. It can be noted that addition of $\mathrm{AlSr}$ refiner slightly increases in hardness. In general, the hardness did not increase with TiBor and $\mathrm{Zr}$ addition (Fig. 5).

Furthermore, investigated alloys were characterised by SEM equipped with EDS and computer-controlled imaging system. The SEM images of analysed Mg-Li-Al alloys point out dark grey and grey areas relating to the $\beta(\mathrm{Li})$ phase and $\alpha(\mathrm{Mg})$ phase, respectively, as shown in Fig. 6a. Because lithium is invisible in SEM image, $\beta$-phase is darker. Grain refinement of analysed magnesium-lithiumaluminium alloy by 0.2 mass $\% \mathrm{Zr}$ causes appearance to
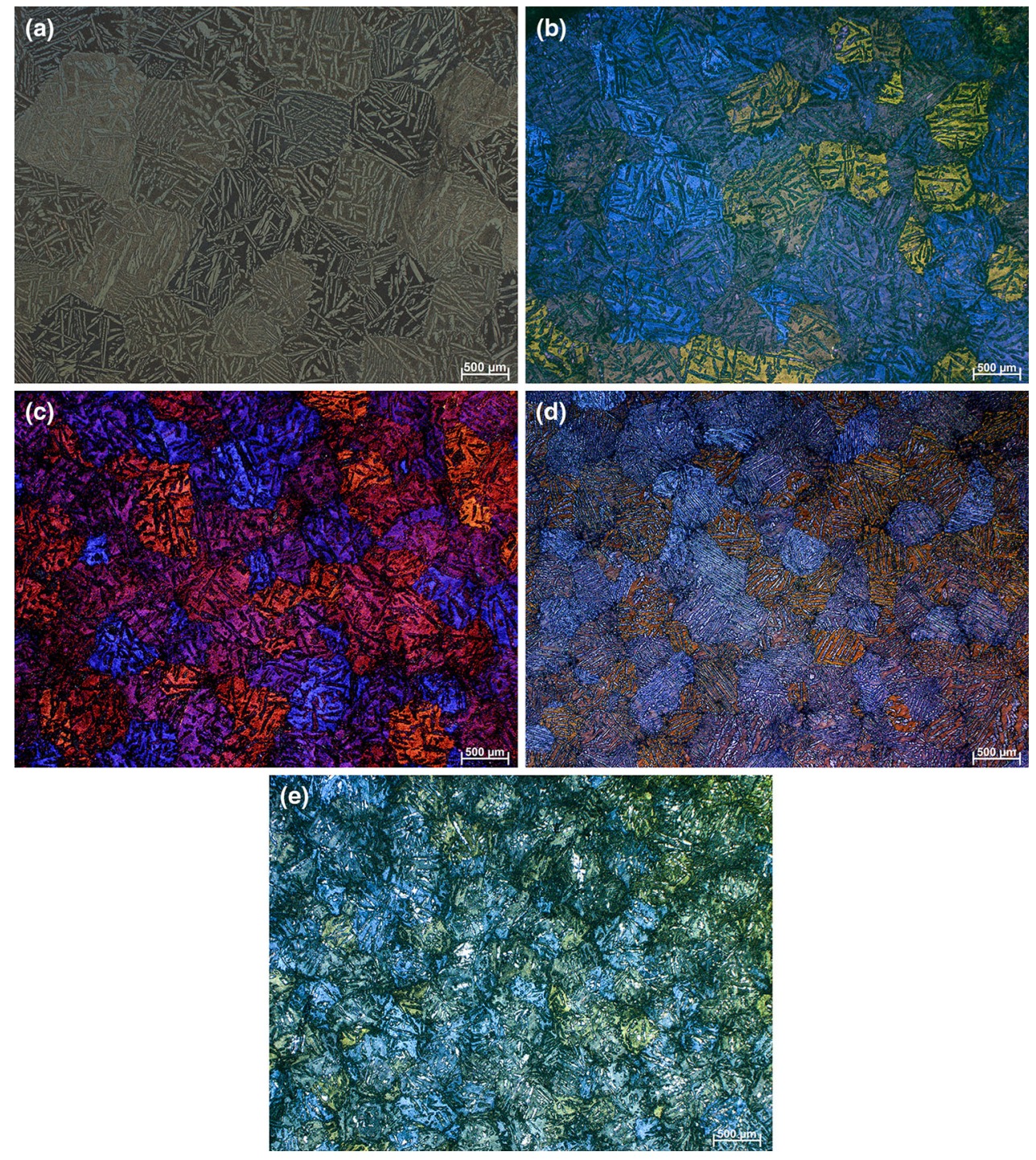

Fig. 3 Microstructure of the grain size for $\mathrm{Mg}-9 \mathrm{Li}-1.5 \mathrm{Al}$ base alloy at various addition of grain refinements: $\mathbf{a}$ Mg-9Li-1.5Al, b $\mathrm{Mg}-9 \mathrm{Li}-$ $1.5 \mathrm{Al}+0.2 \mathrm{Zr}$, $\mathbf{c} \mathrm{Mg}-9 \mathrm{Li}-1.5 \mathrm{Al}+0.2 \mathrm{TiBor}, \mathbf{d ~ M g}-9 \mathrm{Li}-1.5 \mathrm{Al}+0.2 \mathrm{Sr}$, e Mg-9Li-1.5Al+0.2TiBor+0.2Sr, Nomarski contrast 


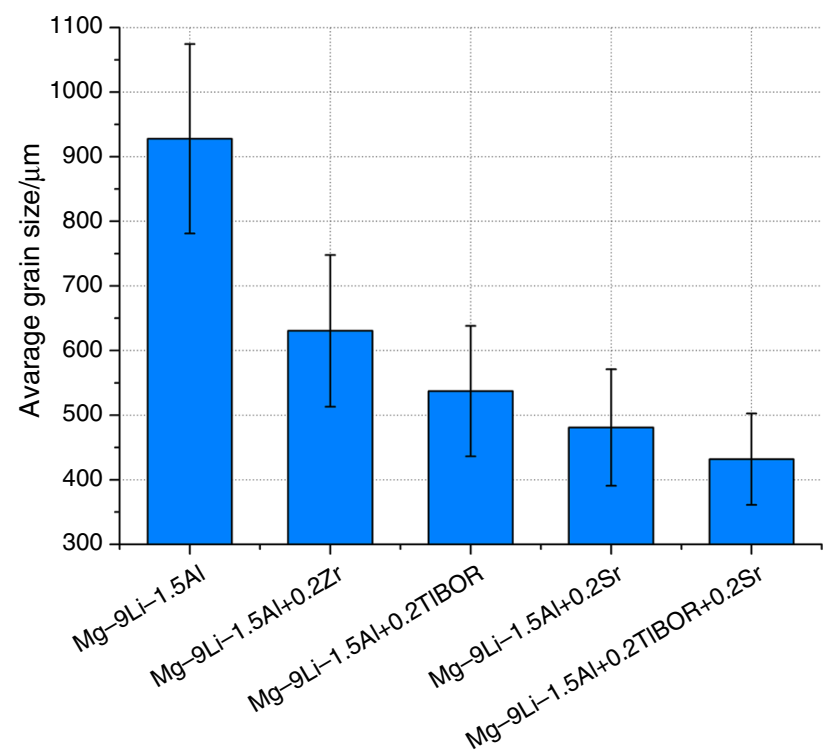

Fig. 4 Grain size of analysed $\mathrm{Mg}-\mathrm{Li}-\mathrm{Al}$ alloys

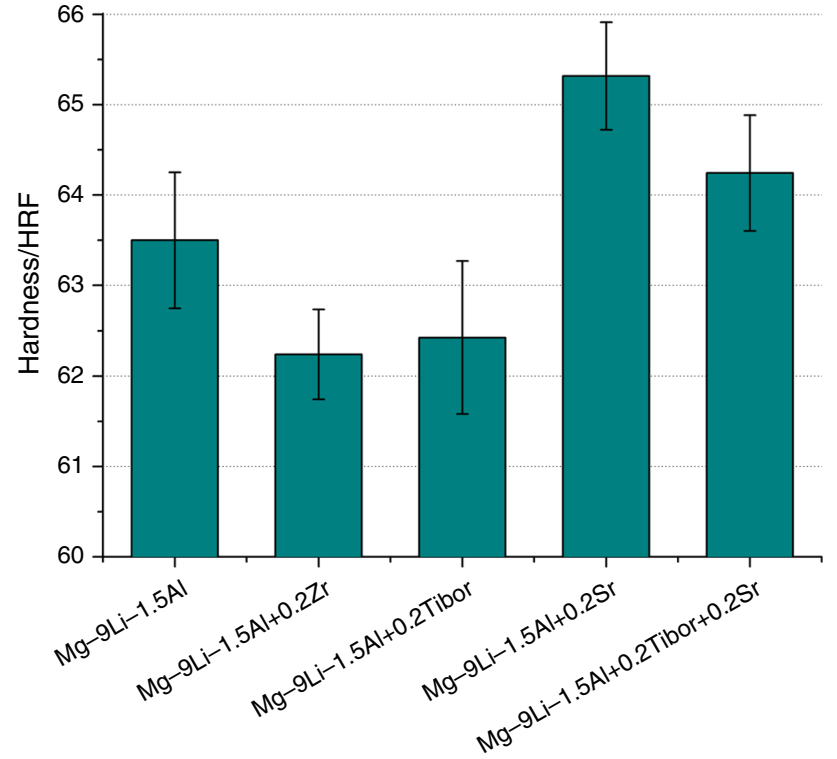

Fig. 5 Hardness of investigated $\mathrm{Mg}-9 \mathrm{Li}-1.5 \mathrm{Al}$ alloys

white granular particles of the intermetallic compounds randomly spread in the $\alpha$ and $\beta$ matrix (Fig. 6b). EDS point analysis carried out on particles (indicated as 3 ) to determine the chemical composition shows that the mixture consists of high concentration of $\mathrm{Zr}, \mathrm{Al}$ and $\mathrm{Mg}$ elements, which the most probably resulted in the form of $\mathrm{Al}_{3} \mathrm{Zr}$ phases as suggested in [21, 22]. With the addition of TiBor master alloy as grain refinement to the $\mathrm{Mg}-9 \mathrm{Li}-1.5 \mathrm{Al}$ alloy, no other phases are observed in microstructure (Fig. 6c).

Figure 6d, e shows the SEM images and EDS analysis of the $\mathrm{Mg}-9 \mathrm{Li}-1.5 \mathrm{Al}+\mathrm{Sr}$ and $\mathrm{Mg}-9 \mathrm{Li}-1.5 \mathrm{Al}+\mathrm{TiBor}+\mathrm{Sr}$ alloys, respectively. Containing $\mathrm{Sr}$, an element with a larger atomic number, bone-like bright intermetallic compounds (indicated as 3) are situated along the phase boundary as well as across $\alpha$-phase. EDS point analysis, which was done at location 3, demonstrates the high concentration of $\mathrm{Mg}, \mathrm{Sr}$ and $\mathrm{Mg}, \mathrm{Al}, \mathrm{Sr}$, respectively. Considering $\mathrm{Al}$ dissolved in the matrix, it can be concluded that these compounds can be related to $\mathrm{Al}_{4} \mathrm{Sr}$ or $\mathrm{Mg}_{2} \mathrm{Sr}$ as suggested in [6]. Shape and location of recognised phases in analysed alloys could be directly related to the order of nucleation in the intermetallic compounds.

The solidification pathways of as-cast (Fig. 7a) and after modification by 0.2 mass\% $\mathrm{Zr}$ (Fig. 7b) and 0.2 mass\% TiBor (Fig. 7c) and 0.2 mass\% AlSr (Fig. 7d) master alloys have been investigated by thermal derivative analysis. Figure 7 a shows typical cooling curves and its first derivative curves which were used to determine characteristic points during solidification. For the alloy with 0.2 mass $\% \mathrm{Zr}$, only five well-defined points are observed, i.e. at $597.7{ }^{\circ} \mathrm{C}\left(1-T_{N}\right.$-nucleation temperature), $578.9^{\circ} \mathrm{C}(2-$ $T_{\mathrm{G}}$-maximum temperature of growth), $526.1{ }^{\circ} \mathrm{C}\left(4-T_{\mathrm{SOL}^{-}}\right.$ solidus temperature), $503.3{ }^{\circ} \mathrm{C}\left(5-T_{\mathrm{S}^{-}} \alpha+\beta\right.$ solvus temperature) and $473.3{ }^{\circ} \mathrm{C}\left(6-T_{\mathrm{ER}}\right.$-end of reactions) as shown in Fig. 7b. No more exothermic peaks were found after modification by $\mathrm{Zr}$ that can be corresponded to compounds of $\mathrm{Al}_{3} \mathrm{Zr}$ as suggested in [21, 22]. It must be noted that the melting temperature of $\mathrm{Al}_{3} \mathrm{Zr}$ intermetallic compound according to the literature [9] is $1580{ }^{\circ} \mathrm{C}$. Results from the thermal derivative analysis (Table 4) present that the addition of 0.2 mass $\% \mathrm{Zr}$ does not change the nucleation temperature, i.e. $596.5{ }^{\circ} \mathrm{C}$ and, however, decreases the solidus temperature from $549.1{ }^{\circ} \mathrm{C}$ of investigated magnesium alloys. For both analysed alloys, no significant changes in temperature in other reactions like $T_{G}, T_{S}$ and $T_{E R}$ were observed. The solidification time for the cooling rate $0.6{ }^{\circ} \mathrm{C} \mathrm{s}^{-1}$, as the difference of the times, at which the liquidus and solidus temperatures occur in $\mathrm{Mg}-9 \mathrm{Li}-1.5 \mathrm{Al}$ and $\mathrm{Mg}-9 \mathrm{Li}-1.5 \mathrm{Al}+0.2 \mathrm{Zr}$, amounts to $\Delta t=106$ and $134 \mathrm{~s}$, respectively.

Addition of TiBor and AlSr causes to appearance new well-defined exothermic peak (marked as point 3 in Fig. 7c-e) probably becomes from nucleation of metastable intermetallic phase $\eta(\mathrm{LiAl})$ with $\mathrm{B} 2$ structure $[8,9,20] 3-\mathrm{T}_{\eta(\mathrm{LiAl})}$ observed at $552.6{ }^{\circ} \mathrm{C}(\mathrm{Mg}-9 \mathrm{Li}-$ $1.5 \mathrm{Al}+\mathrm{TiBor}), \quad 559.1^{\circ} \mathrm{C} \quad(\mathrm{Mg}-9 \mathrm{Li}-1.5 \mathrm{Al}+\mathrm{AlSr}) \quad$ and $546.8{ }^{\circ} \mathrm{C} \quad(\mathrm{Mg}-9 \mathrm{Li}-1.5 \mathrm{Al}+0.2 \mathrm{TiBor}+0.2 \mathrm{Sr})$, however, more studies must be done.

Modification of $\mathrm{Mg}-9 \mathrm{Li}-1.5 \mathrm{Al}$ alloy by $\mathrm{AlSr}$ master alloy causes slight decreases in nucleation temperature to $582.7^{\circ} \mathrm{C}$, but strongly reduces a solidus temperature to $535.3{ }^{\circ} \mathrm{C}$ in accordance with the unmodified alloy. The addition of TiBor and AlSr10 master alloys causes 
(a)

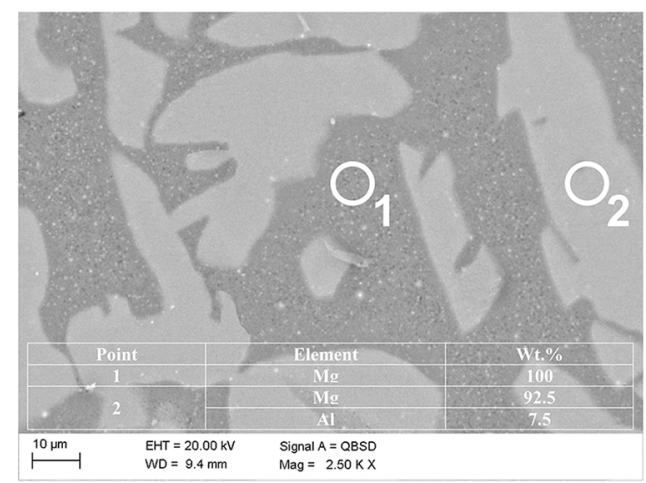

(c)

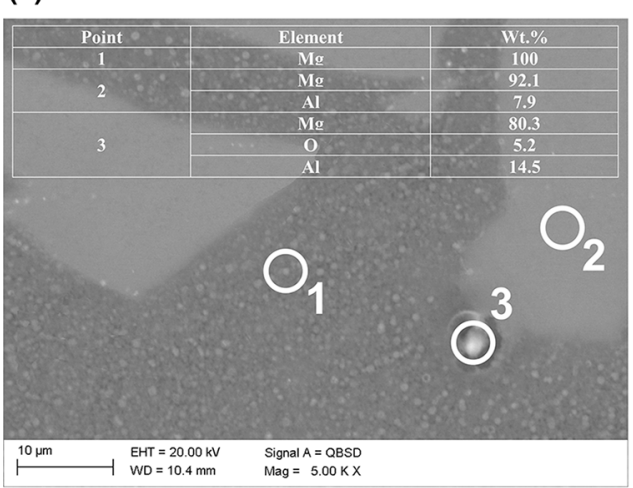

(b)

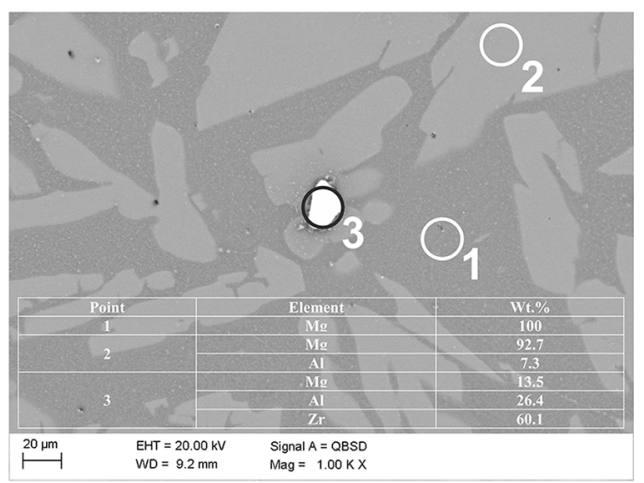

(d)

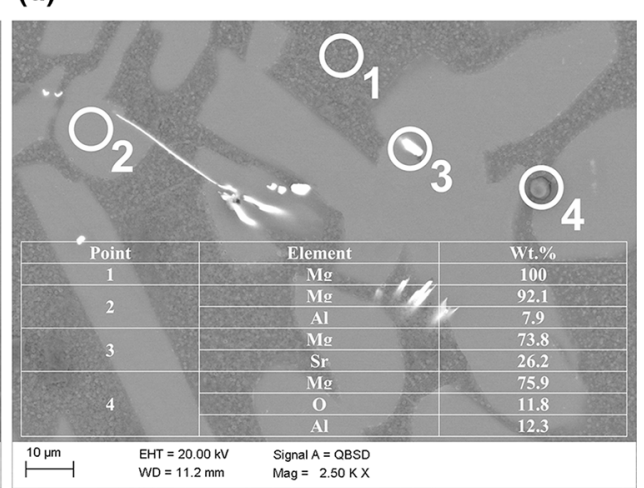

(e)

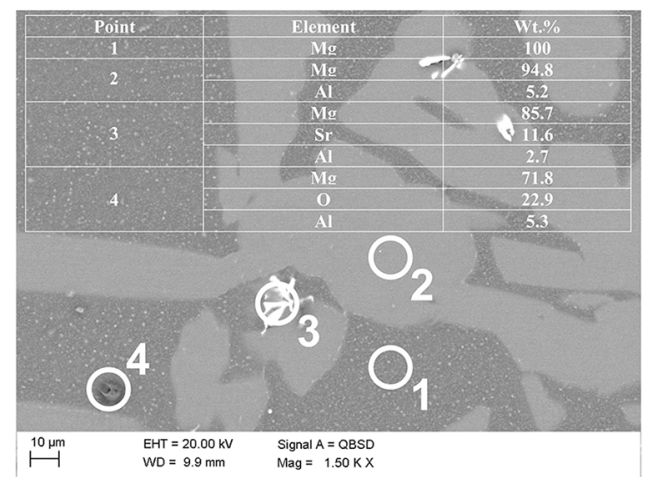

Fig. 6 SEM micrographs with EDS analysis in labelled points of $\mathrm{Mg}-\mathrm{Li}-\mathrm{Al}$ alloys: a $\mathrm{Mg}-9 \mathrm{Li}-1.5 \mathrm{Al}, \mathbf{b} \mathrm{Mg}-9 \mathrm{Li}-1.5 \mathrm{Al}+0.2 \mathrm{Zr}, \mathbf{c} \mathrm{Mg}-9 \mathrm{Li}-$ $1.5 \mathrm{Al}+0.2 \mathrm{TiBor}, \mathbf{d ~ M g}-9 \mathrm{Li}-1.5 \mathrm{Al}+0.2 \mathrm{Sr}$, e $\mathrm{Mg}-9 \mathrm{Li}-1.5 \mathrm{Al}+0.2 \mathrm{TiBor}+0.2 \mathrm{Sr}$

decreases in nucleation temperature and solidus temperature to 579.32 and $520{ }^{\circ} \mathrm{C}$, respectively.

The addition of TiBor and $\mathrm{AlSr}$ master alloys increases a crystallisation time to $132 \mathrm{~s}$ for $\mathrm{Mg}-9 \mathrm{Li}-1.5 \mathrm{Al}+\mathrm{TiB}$ or, 146 $\mathrm{s}$ for $\mathrm{Mg}-9 \mathrm{Li}-1.5 \mathrm{Al}+\mathrm{TiB}$ or and $143 \mathrm{~s}$ for $\mathrm{Mg}-9 \mathrm{Li}-$ $1.5 \mathrm{Al}+0.2 \mathrm{TiBor}+0.2 \mathrm{Sr}$. Moreover, an addition of $\mathrm{Sr}$ causes a reduction in a period between the solidus temperature and solvus temperature. Based on thermal derivative analysis, it was found that only addition of TiBor and $\mathrm{AlSr}$ simultaneously causes a decrease in temperature of maximum growth of primary $\beta(\mathrm{Li})$ phase from 581.3 to $575.6^{\circ} \mathrm{C}$.
In general, no exothermic peaks, corresponding to precipitation of $\mathrm{Mg}_{2} \mathrm{Sr}$, with melting temperature $680{ }^{\circ} \mathrm{C}$ $[8,9]$, were observed during analysis of crystallisation process of $\mathrm{Mg}-\mathrm{Li}-\mathrm{Al}$ alloys containing $\mathrm{Sr}$ as grain refinement. This may be the causes that the amount of $\mathrm{Mg}_{2} \mathrm{Sr}$ intermetallic compound is very low, below the level of detection of the method.

The crystallisation pathway of investigated unmodified and modified magnesium alloys, based on thermal derivative analysis, microstructure investigation, SEM observation and study of binary and ternary systems $[8,9]$, may be proposed as: 

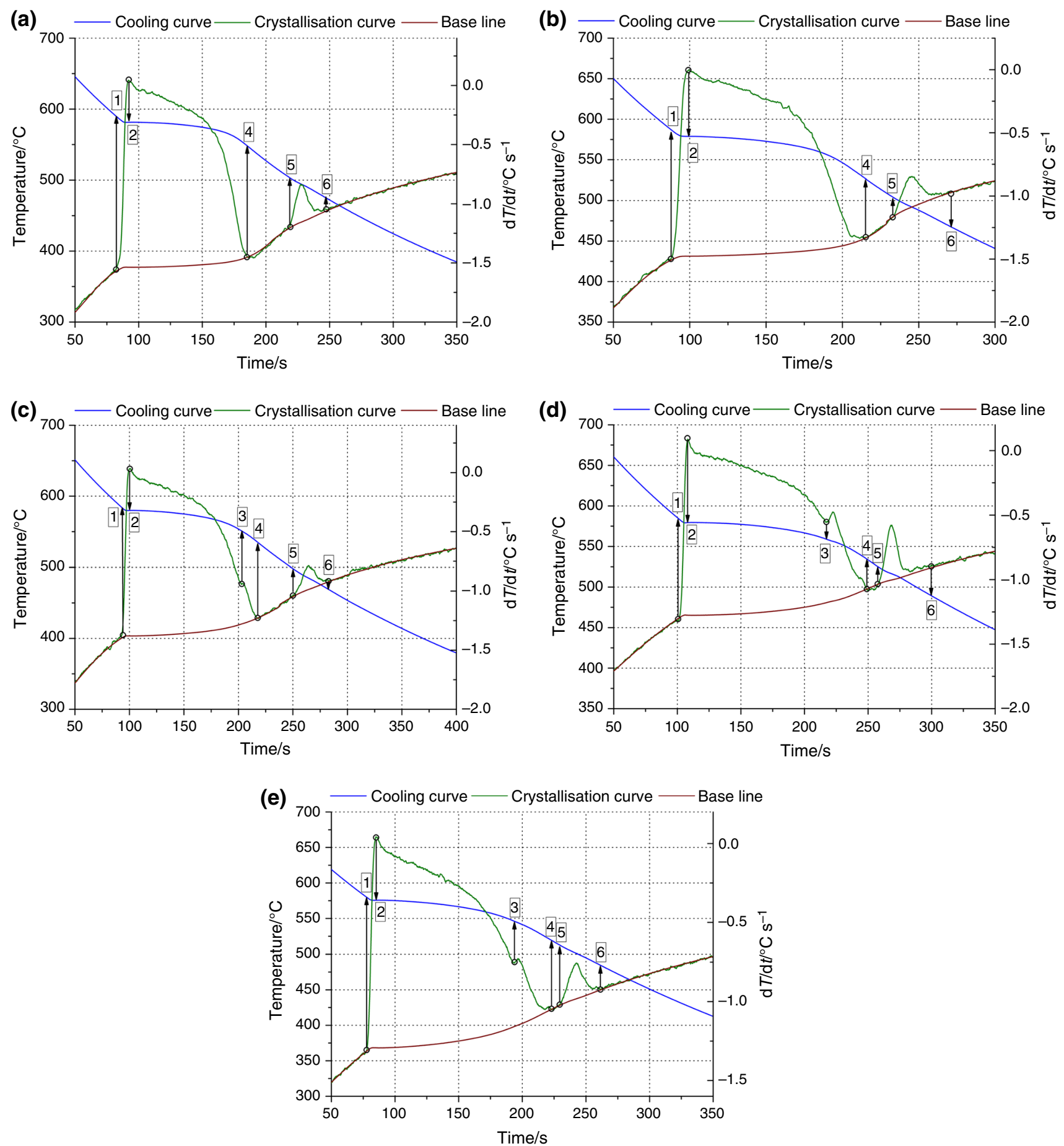

Fig. 7 Representative thermal derivative analysis of investigated $\mathrm{Mg}-\mathrm{Li}-\mathrm{Al}$ alloys: a $\mathrm{Mg}-9 \mathrm{Li}-1.5 \mathrm{Al}, \mathbf{b} \mathrm{Mg}-9 \mathrm{Li}-1.5 \mathrm{Al}+0.2 \mathrm{Zr}, \mathbf{c} \mathrm{Mg}-9 \mathrm{Li}-$ $1.5 \mathrm{Al}+0.2 \mathrm{TiBor}, \mathbf{d ~ M g}-9 \mathrm{Li}-1.5 \mathrm{Al}+0.2 \mathrm{Sr}$, e $\mathrm{Mg}-9 \mathrm{Li}-1.5 \mathrm{Al}+0.2 \mathrm{TiBor}+0.2 \mathrm{Sr}$

1. $L \rightarrow \beta(\mathrm{Li})$

2. Maximum growth of primary $\beta(\mathrm{Li})$-phase

3. $L+\beta(\mathrm{Li}) \rightarrow \alpha(\mathrm{Mg})+\eta(\mathrm{LiAl})$

4. $\beta(\mathrm{Li}) \rightarrow \alpha(\mathrm{Mg})+\beta(\mathrm{Li})$

At first, the $\beta(\mathrm{Li})$ (i.e. a solid solution of alloying elements in lithium) starts solidifying, until the liquid composition reaches the temperature of maximum growth. After passing this point, the phase transition occurs giving $\alpha(\mathrm{Mg})$ phase and $\eta(\mathrm{LiAl})$ intermetallic compound with $\mathrm{B} 2$ structure (only for alloys $\mathrm{Mg}-9 \mathrm{Li}-1.5 \mathrm{Al}+0.2 \mathrm{TiBor}, \mathrm{Mg}-$ $9 \mathrm{Li}-1.5 \mathrm{Al}+0.2 \mathrm{Sr}$ and $\mathrm{Mg}-9 \mathrm{Li}-1.5 \mathrm{Al}+0.2 \mathrm{TiBor}+0.2 \mathrm{Sr}$ ). In the last stage of the crystallisation process of investigated $\mathrm{Mg}-\mathrm{Li}-\mathrm{Al}$ alloys, transition in solid state occurs 
Table 4 Main reactions during solidification identified by thermal derivative analysis

\begin{tabular}{|c|c|c|c|c|c|c|}
\hline & 1. $T_{\mathrm{NUC}} /{ }^{\circ} \mathrm{C}$ & 2. $T_{\mathrm{G}} /{ }^{\circ} \mathrm{C}$ & 3. $T_{\eta(\mathrm{LiAl})} /{ }^{\circ} \mathrm{C}$ & 4. $T_{\mathrm{SOL}} /{ }^{\circ} \mathrm{C}$ & 5. $T_{\mathrm{S}} /{ }^{\circ} \mathrm{C}$ & 6. $T_{\mathrm{ER}} /{ }^{\circ} \mathrm{C}$ \\
\hline Mg-9Li-1.5Al & 596.5 & 581.3 & - & 549.1 & 505.2 & 473.9 \\
\hline $\mathrm{Mg}-9 \mathrm{Li}-1.5 \mathrm{Al}+0.2 \mathrm{Zr}$ & 597.7 & 578.9 & - & 526.1 & 503.3 & 473.3 \\
\hline Mg-9Li-1.5Al+0.2TiBor & 596.3 & 579.8 & 552.6 & 536.4 & 501.3 & 466.6 \\
\hline $\mathrm{Mg}-9 \mathrm{Li}-1.5 \mathrm{Al}+0.2 \mathrm{Sr}$ & 582.7 & 579.3 & 559.1 & 535.3 & 525.0 & 473.7 \\
\hline $\mathrm{Mg}-9 \mathrm{Li}-1.5 \mathrm{Al}+0.2 \mathrm{TiB}$ or $+0.2 \mathrm{Sr}$ & 579.3 & 575.6 & 546.8 & 520 & 513.2 & 474.8 \\
\hline
\end{tabular}

(solvus line in $\mathrm{Mg}-\mathrm{Li}$ binary system) causing forming of $\alpha(\mathrm{Mg})$ and $\beta(\mathrm{Li})$ according to reaction $\beta(\mathrm{Li}) \rightarrow$ $\alpha(\mathrm{Mg})+\beta(\mathrm{Li})$.

\section{Conclusions}

The effects of addition of 0.2 mass\% $\mathrm{Zr}, 0.2$ mass\% TiBor and 0.2 mass $\%$ AlSr grain refiners on the crystallisation process during solidification of the $\mathrm{Mg}-9 \mathrm{Li}-1.5 \mathrm{Al}$ alloy such as $T_{\mathrm{N}}, T_{\mathrm{G}}, T_{\mathrm{SOL}}, T_{\mathrm{S}}$ and $T_{\mathrm{ER}}$, linear coefficient of thermal expansion, microstructure and hardness were studied. The results are summarised as follows:

1. At a $0.6{ }^{\circ} \mathrm{C} \mathrm{s}^{-1}$ cooling rate, the solidification time of $\mathrm{Mg}-9 \mathrm{Li}-1.5 \mathrm{Al}$ alloy is increased by adding grain retirements.

2. In analysed material, an addition of $\mathrm{Zr}$ does not change $T_{\mathrm{N}}, T_{\mathrm{G}}, T_{\mathrm{S}}$ and $T_{\mathrm{ER}}$; however, decreases $T_{\mathrm{SOL}}$. The addition of TiBor and AlSr causes a reduction in nucleation and solidus temperature.

3. Analysis of the heating and cooling dilatometric curves of analysed materials modified by TiBor and AlSr is characterised by a linear reduction in coefficient of linear thermal expansion as a function of temperature. No transitions in the solid state occur during heating and cooling cycles.

4. The as-cast $\mathrm{Mg}-9 \mathrm{Li}-1.5 \mathrm{Al}$ alloy comprises $\alpha(\mathrm{Mg})$ and $\beta(\mathrm{Li})$ phases. AlSr addition results in the formation of new intermetallic compound distributed along the phase boundary as well as across $\alpha$-phase. EDX analysis shows that the precipitated compounds are $\mathrm{Al}_{4} \mathrm{Sr}$ or $\mathrm{Mg}_{2} \mathrm{Sr}$.

5. The addition of $\mathrm{Zr}$, TiBor and AlSr in level 0.2 mass $\%$ reduces the grain size of analysed magnesium alloy. The strongest effect in reduction in grain size (grain size decreased almost twice) was achieved when TiBor and AlSr simultaneously were used.

6. Based on hardness measurements, it was found that the addition of AlSr refiner slightly increases hardness. The hardness did not increase with TiBor addition.
7. Thermal derivative analysis can be implemented to registration melting and cooling processes of $\mathrm{Mg}-\mathrm{Li}-$ Al alloys.

Acknowledgements This work was financed by the Ministry of Science and Higher Education of Poland as the statutory financial grant of the Faculty of Mechanical Engineering SUT.

Open Access This article is distributed under the terms of the Creative Commons Attribution 4.0 International License (http://creative commons.org/licenses/by/4.0/), which permits unrestricted use, distribution, and reproduction in any medium, provided you give appropriate credit to the original author(s) and the source, provide a link to the Creative Commons license, and indicate if changes were made.

\section{References}

1. Liu T, Wu SD, Li SX, Li PJ. Microstructure evolution of Mg$14 \% \mathrm{Li}-1 \% \mathrm{Al}$ alloy during the process of equal channel angular pressing. Mat Sci Eng A Struct. 2007;460-461:499-503.

2. Wang T, Wu R, Zhang M, Li L, Zhang J, Li J. Effects of calcium on the microstructures and tensile properties of $\mathrm{Mg}-5 \mathrm{Li}-3 \mathrm{Al}$ alloys. Mat Sci Eng A Struct. 2011;528:5678-84.

3. Mendis CL, Oh-ishi K, Ohkubo T, Hono K. Effect of Li additions on the age hardening response and precipitate microstructures of $\mathrm{Mg}-2.4 \mathrm{Zn}-0.16 \mathrm{Zr}$ based alloys. Mat Sci Eng A Struct. 2012;535:122-8.

4. Zhanga J, Zhang Y, Wu G, Liu W, Zhanga L, Ding W. Microstructure and mechanical properties of as-cast and extruded Mg-8Li-3Al-2Zn-0.5Nd alloy. Mat Sci Eng A-Struct. 2015;621:198-203.

5. Bao L, Zhang Z, Le Q, Li Q, Cui J. Influence of Gd, Nd and Ce additions on microstructures and mechanical properties of ultralight dual phase $\mathrm{Mg}-9 \mathrm{Li}-0.4 \mathrm{Zr}$ alloys. Mater Res-Ibero-Am J. 2016;19(3):654-8.

6. Xu T, Peng X, Jiang J, Xie W, Chen Y, Wei G. Effect of Sr content on microstructure and mechanical properties of $\mathrm{Mg}-\mathrm{Li}-$ Al-Mn alloy. T Nonferr Metal Soc. 2014;24:2752-60.

7. Chenga R, Pana F, Jiang S, Li Ch, Jiang B, Jiang X. Effect of Sr addition on the grain refinement of AZ31 magnesium alloys. Prog Nat Sci-Mater. 2013;23(1):7-12.

8. Goel NC, Cahoon JR. The Al-Li-Mg system (AluminumLithium-Magnesium). Bulletin of Alloy Phase Diagrams. 1990;11:528. https://doi.org/10.1007/BF02841712.

9. A.I.H. Committee, ASM Handbook, volume 3: alloy phase diagrams, 10th ed. ASM International: The Materials Information Company; 1992. 
10. Król M, Tański T, Matula G, Snopiński P, Tomiczek AE. Analysis of crystallisation process of cast magnesium alloys based on thermal derivative analysis. Arch Metall Mater. 2015;60(4):2993-9. https://doi.org/10.1515/amm-2015-0478.

11. Król M, Tański T, Sitek W. Thermal analysis and microstructural characterization of $\mathrm{Mg}-\mathrm{Al}-\mathrm{Zn}$ system alloys. Modern Technologies in Industrial Engineering (MODTECH2015), Book Series: IOP Conference Series-Materials Science and Engineering 2015. https://doi.org/10.1088/1757-899x/95/1/012006.

12. Sroka M, Zieliński A, Dziuba-Kałuża M, Kremzer M, Macek M, Jasiński A. Assessment of the residual life of steam pipeline material beyond the computational working time. Metals-Basel. 2017;7(3):82. https://doi.org/10.3390/met7030082.

13. Zieliński A, Sroka M, Miczka M, Śliwa A. Forecasting the particle diameter size distribution in P92 (X10CRWMOVNB9-2) steel after long-term ageing at 600 and $650 \& \# x B 0 ; C$. Arch Metall Mater. 2016;61(2A):753-60. https://doi.org/10.1515/ amm-2016-0128.

14. Król M, Tański T, Snopiński P, Tomiczek B. Structure and properties of aluminium-magnesium casting alloys after heat treatment. J Therm Anal Calorim. 2017;127:299-308. https://doi. org/10.1007/s10973-016-5845-4.

15. Meylan B, Terzi S, Gourlay CM, Dahle AK. Dilatancy and rheology at $0-60 \%$ solid during equiaxed solidification. Acta Mater. 2011;59:3091-101.
16. Yavari F, Shabestari S. Effect of cooling rate and $\mathrm{Al}$ content on solidification characteristics of AZ magnesium alloys using cooling curve thermal analysis. $J$ Therm Anal Calorim. 2017;129(2):655-62.

17. Jafari H, Khalilnezhad M, Farahany S. Computer-aided cooling curve thermal analysis and microstructural evolution of $\mathrm{Mg}-5 \mathrm{Zn}-$ xY cast alloys. J Therm Anal Calorim. 2017;130(3):1429-37.

18. Zovko Brodarac Z, Holjevac Grgurić T, Burja J. Thermodynamic stability of AlSi11 alloy microconstituents. J Therm Anal Calorim. 2017;127(1):431-8.

19. Dutkiewicza J, Rusz S, Maziarz W, Skuza W, Kuc D, Hilser O. Modification of microstructure and properties of extruded $\mathrm{Mg}$ Li-Al alloys of $\alpha$ and $\alpha+\beta$ phase composition using ECAP processing. Acta Phys Pol A. 2017;131:1303-6.

20. Wu R, Yan Y, Wang G, Murr LE, Han W, Zhang Z, Zhang M. Recent progress in magnesium-lithium alloys. Int Mater Rev. 2015;60(2):65-100.

21. Stjohn DH, Easton MA, Qian M, Taylor JA. Grain refinement of magnesium alloys: a review of recent research, theoretical developments, and their application. Metall Mater Trans A. 2012;44A:2935-49.

22. Friedrich HE, Mordike BL. Magnesium technology metallurgy, design data, applications. Berlin: Springer-Verlag; 2006. 